\title{
Pengembalian Modal Usaha Program Komunitas Usaha Mikro Muamalat Berbasis Masjid Kota Bogor
}

\author{
Venture Capital Returns Micro Communities Program Muamalat \\ Based Bogor City Mosque
}

\author{
Kostia Digdaha ${ }^{1 *}$, Rizal Syarif ${ }^{2 \sharp}$, dan MH Bintoro Djoefrie ${ }^{3 \sharp}$ \\ ${ }^{1}$ Baitul Maal Muamalat Jakarta; Program Magister Industri Kecil Menengah, Sekolah Pascasarjana IPB \\ ${ }^{2}$ Departemen Teknologi Industri Pertanian, Fakultas Teknologi Pertanian Institut Pertanian Bogor \\ ${ }^{3}$ Departemen Budidaya Pertanian, Fakultas Pertanian Institut Pertanian Bogor \\ * Jl. Kamper Kampus IPB Darmaga, Bogor 16680
}

\begin{abstract}
ABSTRAK
Kepedulian Bank Muamalat dalam mengentaskan kemiskinan bekerja sama dengan Baitul Maal Muamalat (BMM), telah melakukan program Komunitas Usaha Mikro Muamalat Berbasis Masjid (KUM3). Program tersebut mempunyai permasalahan, yaitu banyaknya anggota KUM3 dalam pengembalian modal usaha tidak tepat waktu sehingga tidak dapat digulirkan kembali. Penelitian ini bertujuan menganalisis faktor-faktor yang memengaruhi pengembalian modal usaha KUM3, Penelitian dilakukan di empat komunitas, yaitu di Kecamatan Bogor Barat (Komunitas Loji dan Situ Gede), komunitas Pamoyanan di Kecamatan Bogor Selatan dan komunitas Pasar Anyar di Kecamatan Bogor Tengah. Penelitian menguji delapan faktor yang dapat mempengaruhi pengembalian modal usaha, yaitu nilai sosial, nilai teori, nilai ekonomi, nilai agama, pemasaran, keuangan, manajerial dan teknis. Metode yang digunakan dalam menganalisis data dengan model logistik berganda. Hasil analisis diperoleh kondisi peserta KUM3 Kota Bogor mempunyai nilai sosial $(1,866)$, nilai teori $(19,92)$, nilai ekonomi ($33,45)$, nilai agama $(1,242)$, pemasaran $(18,842)$, keuangan $(32,343)$, manajerial $(-4,11)$, dan teknis $(17,12)$. Nilai sosial, nilai ekonomi, kemampuan usaha berpengaruh nyata terhadap peluang pengembalian modal usaha. Faktor yang paling berpengaruh dalam pengembalian modal usaha adalah nilai sosial memiliki kecenderungan pengembalian modal usaha tepat waktu lebih cepat 6,46 kali. Kategori nilai sosial baik memiliki kecenderungan pengembalian modal usaha tepat waktu 7.000 kali dibandingkan nilai sosial kurang baik. Berdasarkan perbandingan faktor keluarga dan masyarakat pada nilai sosial keduanya memiliki pengaruh terhadap pengembalian modal usaha.
\end{abstract}

Kata kunci: masjid, pengembalian modal usaha, program komunitas usaha

\begin{abstract}
In the process of eradicating poverty, Bank Muamalat with the collaboration with the Baitul Maal Muamalat (BMM), has undertaken the Mosque Based Micro Muamalat Community Program (KUM3). The problem identified in the program is that many members of KUM3 cannot make a capital return at the right time, causing them to fail in re-threading the capital. This study aims to determine the factors that affect the KUM3 member's capital returns. Investigations carried out in four districts in Bogor City namely the Community of Loji, Pamoyanan, Pasar Anyar and Situ Gede. Eight factors that might affect the business capital was studied i.e. the value of social capital, the theory, the economy, the religion, marketing, finance, management and technical. The method used in analysing the data is the multiple logistic model. The analysis obtained a good results in the social value, theoretical value, the economy, the religion, marketing, finance, management, and technical for the KUM3 participants in Bogor City. The most influential factor in the return of capital is the social value. Two factors were studied in this value i.e. family factor and community factor. It has a tendency to break on time 6.46 times faster with the value of the regression coefficient 1.946 and value of $-\mathrm{p} 0.010(<0.05)$ compared to the social
\end{abstract}

\footnotetext{
*) Korespondensi:

Jl. Raya Puncak Warung Sari, Ciawi, Bogor; email: digdaha@yahoo.com
} 
disadvantage significance level of $5 \%$. The good social value has a tendency to break even at 7,000 times compared to the less good social value. Based on the comparison between the family factor and the community factor, both have an impact on the capital returns.

Key words: capital returns, character, KUM3, logistic model

\section{PENDAHULUAN}

Menurut BPS (2014), jumlah penduduk Indonesia yang masuk kategori miskin pada tahun 2013 mencapai 11,23\% atau setara 27,48 juta penduduk. Pemerintah Indonesia saat ini telah meluncurkan program penanggulangan kemiskinan seperti BLT (Bantuan Langsung Tunai), KUR (Kredit Usaha Rakyat) pengembangan Usaha Mikro Kecil Menengah (UMKM) dan Program Nasional Pemberdayaan Masyarakat Mandiri (PNPM Mandiri). Program penanggulangan kemiskinan tersebut belum mampu mengentaskan kemiskinan bagi usaha kecil dan menengah (UKM) secara maksimal.

Salah satu bentuk kepedulian Bank Muamalat Indonesia Tbk. (BMI) dalam mengentaskan kemiskinan, dengan mendorong komunitas usaha mikro dan pemberdayaan masyarakat berbasis masjid (KUM3), bekerjasama dengan Baitul Maal Muamalat (BMM). Program pemberdayaan KUM3 merupakan pendayagunaan dana ZIS (Zakat, Infaq dan Sedekah) dari nasabah BMI. Program tersebut mengedepankan pembinaan usaha dan pendampingan keagamaan, disamping pemberian modal awal dan pembinaan bagi calon penerima manfaat. Usaha kecil dan menengah diharapkan mampu mengelola keuangan dan mengembangkan usahanya menjadi lebih baik, sehingga dapat meningkatkan perekonomian dan spiritual, serta memberikan teladan bagi anggota keluarga yang lain. Secara garis besar program KUM3 mempunyai tiga kegiatan, yaitu:

1. Pemberdayaan

Pemberdayaan dilakukan secara bertahap kepada UKM komunitas masjid dengan beberapa bentuk pemberian modal usaha, yaitu dengan akad Al-Qardrul Hasan (Pinjaman Tanpa Faedah), Al-Qardh (akad pinjaman) dan Al-Musyarakah (akad kerjasama).

2. Kemitraan strategik

Program lanjutan setelah program pemberdayaan dianggap telah memenuhi harapan, yaitu setiap modal yang diberikan kepada UKM akan dilakukan pendampingan dengan memberikan pembinaan kepada mustahik seperti pelatihan manajemen keuangan, pemasaran dan produksi.

3. Pembinaan mental spiritual

Kegiatan pembinaan mental spiritual yang diterapkan, yaitu membiasakan dan melatih shalat berjamaah, bersedekah, silaturahmi, shaum, baca quran, dan pengajian rutin.

BMM menerima ziswaf muzaki (orang yang membayar zakat, infaq dan wakaf) dari nasabah BMI, kemudian menyalurkannya kepada mustahik (orang yang menerima zakat, infak dan wakaf) melalui program (KUM3). Kerjasama BMM dengan Departemen Agama adalah memberikan rekomendasi masjid yang akan dijadikan basis KUM3, kemudian masjid memberikan data base UKM dari jamaah masjid yang selanjutnya BMM akan memberikan pendampingan dan memberikan modal usaha. Pendamping melakukan pengawasan usaha (kelancaran pembayaran angsuran) dan pembinaan dengan menggunakan sarana masjid sebagai basis pembinaan dan pengawasannya. Tingkat pengembalian modal usaha tidak tepat waktu (bermasalah) pada tahun 2013 75,21\%

\section{METODE PENELITIAN}

Obyek penelitian pada program KUM3 Kota Bogor, yaitu komunitas Pamoyanan, Situ Gede, Sindang Barang dan Pasar Anyar. Teknik pengumpulan data menggunakan kuesioner yang diisi oleh pendamping UKM. Kuesioner tersebut berisi informasi tentang peserta program KUM3. Selain melalui kuesioner, informasi diperoleh melalui wawancara dengan pihak BMM dan pendamping. Penyusunan struktur pertanyaan atau pernyataan serta jawabannya digunakan format Skala Likert. Hasil kuesoner dihitung dengan memberikan skor. Format kuesioner untuk membuat pernyataan responden berbentuk multiple choice (pilihan ganda). Untuk keperluan analisis kuantitatif, pemberian skor untuk setiap item kuesioner menggunakan skala Likert yang jumlahnya ganjil (1-5). Jawaban dari setiap instrument yang menggunakan skala Likert mempunyai gradasi dari sangat positif sampai sangat negatif berupa kata-kata, untuk keperluan analisis kuantitatif. 
Variabel X merupakan karakter dan usaha responden yang diukur dengan sikap yang menyatakan baik atau tidak baik dengan 5 skala, yaitu sangat tidak baik (1), kurang baik (2), baik (3), dan sangat baik (4) dan sangat baik sekali (5). Variabel Y adalah pembayaran UKM tepat waktu atau tidak, yaitu tergolong tepat waktu (1), tidak tepat waktu (0).

Pada penelitian tersebut dilakukan definisi sebagai berikut:

1. Modal usaha pada program KUM3 didefinisikan pengembalian modal usaha tepat waktu sangat kecil, dimana kesulitan pengembalian modal usaha ini dipengaruhi oleh karakter dan kemampuan UKM.

2. Pendamping merupakan karyawan yang ditugaskan untuk mendampingi UKM dengan memberikan penilaian terhadap karakter sosial, pengetahuan, ekonomi dan agama.

3. Kemampuan UKM meliputi pemasaran, keuangan, manajerial dan teknis UKM KUM3.

Tanggapan reponden berkisar dari rentang skala 1-5, yang bermakna mulai sangat tidak baik sampai yang bermakna sangat baik sekali. Indikator dari masing-masing peubah dapat berpengaruh terhadap pengembalian modal usaha UKM yaitu:

1. Nilai Sosial

Hubungan UKM KUM3 dengan orang lain, baik individu dengan invidu, individu dengan kelompok, maupun kelompok dengan kelompok lainnya. Hubungan sosial yang dapat memengaruhi tingkat pengembalian modal usaha bermasalah terjadi di keluarga, tetangga, dan di kantor/lingkungan kerja

2. Nilai Teori

Wawasan yang dimiliki oleh UKM, baik yang bersifat umum seperti pendidikan formal maupun khusus seperti yang berkaitan dengan pinjam-meminjam.

3. Nilai Ekonomi

Kegiatan ekonomi UKM didalam mengelola keuangannya meliputi pemasukan, pengeluaran dan pengelolaan keuangan.

4. Nilai Religius

Pemahaman UKM tentang agama Islam, yaitu aqidah, ibadah dan akhlak.

5. Pemasaran

Menilai bagaimana strategi pemasaran yang dilakukan UKM berdasarkan kondisi pasar dari usahanya.

6. Keuangan
Kemampuan UKM tentang bagaimana memperoleh sumber-sumber dana dan cara menggunakannya, serta bagaimana UKM dapat mengelola keuangan usahanya.

7. Manajerial

Menilai kemampuan dan keterampilan UKM melaksanakan fungsi-fungsi manajemen dalam memimpin perusahaan, seperti marketing, stok, kepemimpinan dan pelayanan terhadap konsumen.

8. Teknis

Menilai kemampuan calon mudharib dalam mengelola usahanya, seperti seberapa besar kemampuan UKM dalam membuat atau menyiapkan barang atau jasa yang akan dijual.

Peubah-peubah yang dianalisis dalam penelitian ini:

1. Peubah terikat

Peubah terikat pada pengembalian modal usahap KUM3 adalah penilaian tepat waktu (0) dan penilaian tidak tepat waktu (1).

2. Peubah bebas, didefinisikan sebagai berikut:

a. Nilai sosial berharga 1, bila responden mempunyai nilai sosial kurang baik dan berharga 0 , bila responden mempunyai nilai sosial baik.

b. Nilai teori berharga 1, bila responden mempunyai nilai teori kurang baik dan berharga 0 , bila responden mempunyai nilai teori baik.

c. Nilai ekonomi berharga 1, bila responden mempunyai nilai ekonomi kurang baik dan berharga 0 , bila responden mempunyai nilai ekonomi baik.

d. Nilai religius berharga 1, bila responden mempunyai nilai religius kurang baik dan berharga 0 , bila responden mempunyai nilai religius baik.

e. Pemasaran berharga 1, bila responden mempunyai pemasaran kurang baik dan berharga 0 , bila responden mempunyai pemasaran baik.

f. Financial berharga 1, bila responden mempunyai financial kurang baik dan berharga 0 , bila responden mempunyai financial baik.

g. Manajemen berharga 1, bila responden mempunyai manajemen kurang baik dan berharga 0 , bila responden mempunyai manajemen baik. 
h. Teknis berharga 1, bila responden mempunyai teknis kurang baik dan berharga 0 , bila responden mempunyai teknis baik.

Pengembalian modal usaha tidak tepat waktu bisa terjadi akibat kesalahan analisis dari shahibul maal dalam memberikan modal usahanya, diperlukan analisis tepat, supaya modal usaha yang diberikan kepada mudharib dapat berjalan menurut kesepakatan yang telah diperjanjikan. Penelitian calon mudhorib menggunakan dua prinsip, yaitu karakter dan kemampuan.

Dalam penelitian ini, dari kelima pendekatan yang disebutkan, hanya digunakan tiga pendekatan, yaitu pendekatan financial (keuangan), pendekatan manajerial, dan pendekatan teknis. Pendekatan yuridis tidak digunakan karena semua UKM dari KUM3 ini tidak mempunyai legalitas usaha, sehingga faktor tersebut tidak diperlukan dalam penelitian.

Penjelasan dari ketiga pendekatan tersebut adalah:

1. Pendekatan Keuangan

Penelitian dan penilaian meliputi hal-hal yang menyangkut keadaan keuangan perusahaan. Menurut Rivai (2008), informasi keuangan yang perlu diketahui dari calon mudharib adalah:

a. Pemeriksaan piutang dagang dengan catatan yang ada di perusahaan (misalnya nota-nota tagihan kepada para pelanggan perusahaan dan catatan/buku pembantu piutang).

b. Pemeriksaaan hutang perusahaan.

c. Pemeriksaan laba perusahaan.

d. Neraca perkiraan rugi/laba dua atau tiga tahun terakhir dengan melihat likuiditas, solvabilitas, rentabilitas dan rasio-rasio keuangan.

e. Konfirmasi kepada calon mudarib hal-hal yang meragukan dalam laporan keuangan mudharib dan cross check data laporan keuangan dengan yang ada di lapangan.

f. Kerapihan dan keakuratan data keuangan perusahaan. Jumlah modal kerja yang tersedia sebelum mengajukan pembiayaan.

Selain itu, ada pembinaan dan pelatihan yang dilakukan oleh para pendamping untuk memberikan pemahaman tentang keuangan kepada UKM KUM3.

2. Pendekatan Manajerial

Aspek manajemen (Rivai, 2008) meliputi:

a. Bagaimana bentuk dan sifat organisasi, serta wewenang dan tanggung jawab setiap tingkat atau bagian yang ada dalam struktur organisasi.

b. Kemampuan, yakni kemampuan pribadi calon mudharib dalam menjalankan dan mengatur usahanya.

c. Kewibawaan, yakni untuk mengetahui reputasi manajer dan perusahaan dalam masyarakat, serta untuk mengetahui gaya kepemimpinan, apakah mudharib yang bersangkutan mempunyai gaya kepemimpinan.

d. Mental dari pengelola perusahaan. Dalam bisnis yang terpenting mental. Mental memerlukan latihan, pengalaman, kesabaran, ketangguhan, keuletan, inovatif, dan yang paling penting berani menghadapi risiko (Najma, 2008).

e. Pengalaman dan pendidikan mudharib.

f. Budaya perusahaan, yakni kebiasaankebiasaan pengurus perusahaan, seperti kedisiplinan waktu dan konsentrasi dalam bekerja (Rivai, 2008).

3. Pendekatan Teknis

Beberapa hal yang perlu diperhatikan dalam menentukan luas produksi usaha adalah:

a. Bahan dasar yang digunakan dalam proses produksi.

b. Produk yang dihasilkan.

c. Besar kecilnya mesin yang digunakan.

d. Jumlah tenaga kerja yang terlibat dalam proses produksi.

Penentuan alat-alat produksi yang digunakan berkaitan erat dengan keuntungan dan kerugian jangka panjang. Ketepatan alat produksi akan menunjang keuntungan jangka panjang karena pemilik usaha dapat mengoptimalkan penggunaan alat tersebut. Sebaliknya, kesalahan dalam memilih alat-alat produksi akan memaksa pemilik usaha untuk mengganti alat tersebut. Jika ini terjadi maka pemilik usaha sama saja melakukan investasi dua kali untuk pekerjaan yang sama. Beberapa hal yang perlu diperhatikan dalam memilih alat-alat produksi adalah kesesuaian dengan teknologi, kesesuaian harga peralatan dengan kemampuan keuangan, kemampuan atau kapasitas produksi peralatan, ketersediaan suku cadang dan perawatan, kualitas serta umur ekonomis. Teknologi senantiasa berkembang dari masa ke masa, meskipun demikian, teknologi baru tidak selalu cocok diterapkan pada proses produksi usaha yang sedang dikembangkan. 


\section{Lokasi Perusahaan}

Penentuan lokasi produksi dapat dilakukan dengan pertimbangan jenis usaha yang akan atau sedang dikembangkan. Beberapa hal yang perlu diperhatikan dalam penentuan lokasi produksi adalah:

1. Ketersediaan bahan mentah

2. Letak pasar yang dituju

3. Ketersediaan sumber energi, air dan sarana telekomunikasi

4. Ketersediaan sarana transportasi

Luas atau skala produksi masing-masing usaha berbeda satu dengan yang lain. Luas produksi sangat penting untuk direncanakan agar usaha yang dikembangkan mencapai tingkat keuntungan maksimal.

\section{Tenaga Kerja}

Penggunaan tenaga kerja atau buruh, baik kuantitas maupun mutunya, meliputi:

a. Komposisi tenaga kerja yang digunakan.

b. Dari mana dan bagaimana cara memperoleh tenaga kerja.

c. Keahlian dari setiap tenaga kerja.

d. Ada atau tidaknya penggunaan tenaga ahli secara khusus dan cara penyediaan tenaga ahli tersebut.

e. Struktur upah dan jaminan sosial.

f. Program pelatihan untuk peningkatan kemampuan.

\section{Bahan baku}

a. Jenis bahan baku yang diperlukan.

b. Sumber dan bagaimana cara mendapatkan bahan baku tersebut.

c. Kelangsungan ketersediaan bahan baku.

Jumlah kebutuhan bahan baku primer dan bahan baku sekunder per bulannya, baik pada kapasitas riil maupun teknis. Jumlah stok bahan baku dan bahan jadi pada saat pengajuan pembiayaan serta berapakah rendemen bahan dasar terhadap bahan jadi.

Ketahanan bahan baku yang disimpan tanpa perubahan mutu.

f. Perencanaan penyediaan bahan baku minimal selama jangka waktu pembiayaan.

Peubah keuangan, manajerial dan teknis dijadikan indikator dalam penelitian ini. Selain tiga pendekatan menurut Rivai (2008) bahwa pemasaran merupakan salah satu faktor penting dalam suatu usaha. Skor yang diperoleh dari jawaban responden atas pertanyaan atau pernyataan mengenai peubah penelitian, padahal faktor karakter yang terdiri dari peubah nilai sosial, nilai teori, nilai ekonomi, dan nilai agama dan faktor kemampuan yang terdiri dari peubah pemasaran, keuangan, manajerial, dan teknis. Peubah tersebut dianalisis dengan statistik deskriptif yang didukung oleh data primer dan studi pustaka untuk memperkuat dan memperdalam hasil analisis.

\section{HASIL DAN PEMBAHASAN}

Skor diperoleh dari jawaban responden atas pertanyaan atau pernyataan mengenai peubah penelitian, yaitu faktor karakter terdiri atas peubah nilai sosial, nilai teori, nilai ekonomi dan nilai agama, sedangkan faktor kemampuan terdiri atas peubah pemasaran, keuangan, manajerial, dan teknis. Peubah dianalisis dengan statistik deskriptif yang didukung oleh data primer dan studi pustaka untuk memperkuat dan memperdalam hasil analisis.

\section{Analisis Deskriptif}

Analisis data deskriptif bertujuan memberikan gambaran mengenai obyek penelitian menurut data dan peubah yang diperoleh. Untuk memudahkan dalam menginterpretasikan hasil penelitian, dalam Tabel 1 digunakan penafsiran data berikut:

$0 \%=$ tidak seorangpun dari responden, $1 \%-25 \%=$ sangat sedikit dari responden,

$26 \%-49 \%=$ sebagian kecil/hampir setengah dari responden,

$50 \%=$ setengah dari responden,

$51 \%-76 \%$ = sebagian besar dari responden,

77\%-99\% =hampir seluruh dari responden, 100\%= Seluruh responden (Arikunto, 1998).

Dari Tabel 1 dapat dilihat bahwa hampir seluruh responden KUM3 memiliki nilai sosial baik dan sebagian kecil responden memiliki kemampuan teknis baik. Secara sebagian besar responden Bogor memiliki kategori baik (54\%). Selanjutnya setiap jawaban pertanyaan dari kuesioner dijumlahkan dan dilakukan skor rataan untuk melihat peringkat paling tinggi.

Tabel 2 menggambarkan bahwa peringkat pertama yang memiliki kategori cukup baik adalah nilai sosial dengan skor 3,72. Peringkat kedua nilai keagamaan (skor 3,24) dan peringkat ketiga nilai ekonomi (skor 3,20). Peubah nilai teori, kemampuan usaha, manajerial dan teknis memiliki skor rataan yang tidak jauh beda, 
sehingga responden memiliki kategori baik. Peubah keuangan merupakan peringkat terakhir dengan skor rataan 2,78, dimana sebagian responden memiliki kategori kurang baik.

Tabel 1. Nilai responden dari setiap peubah

\begin{tabular}{clcc}
\hline No & \multicolumn{1}{c}{ Peubah } & Baik (\%) & Tidak baik (\%) \\
\hline $\mathbf{1}$ & Nilai Sosial & $\mathbf{7 8}$ & $\mathbf{2 2}$ \\
$\mathbf{2}$ & Nilai Keagamaan & $\mathbf{4 6}$ & $\mathbf{5 4}$ \\
$\mathbf{3}$ & Nilai Ekonomi & $\mathbf{4 2}$ & $\mathbf{5 8}$ \\
4 & Nilai Teori & 48 & 52 \\
5 & Kemampuan & 62 & 38 \\
$\mathbf{6}$ & Manajerial & 58 & 42 \\
7 & Teknis & 46 & 54 \\
8 & Keuangan & 52 & 48 \\
\hline & Total rataan & $\mathbf{5 4}$ & $\mathbf{4 6}$ \\
\hline
\end{tabular}

\section{Analisis khi kuadrat}

Analisis hubungan dua peubah dengan analisis khi kuadrat untuk mendeteksi ada tidaknya hubungan dua faktor pada peubah dengan tingkat pengembalian modal usaha. Peluang dari setiap peubah menyebabkan tepat waktu dan tidak tepat waktu. Peluang memiliki hubungan nyata (nilai peluang 0,01-0,110).

Tabel 2. Peringkat skor rataan peubah

\begin{tabular}{clcc}
\hline No & \multicolumn{1}{c}{ Peubah } & $\begin{array}{c}\text { Skor } \\
\text { Rataan }\end{array}$ & Keterangan \\
\hline $\mathbf{1}$ & Nilai Sosial & $\mathbf{3 , 7 2}$ & Cukup Baik \\
$\mathbf{2}$ & Nilai Keagamaan & $\mathbf{3 , 2 4}$ & Baik \\
$\mathbf{3}$ & Nilai Ekonomi & $\mathbf{3 , 2 0}$ & Baik \\
4 & Nilai Teori & 3,11 & Baik \\
5 & Kemampuan & 3,16 & Baik \\
$\mathbf{6}$ & Manajerial & 3,09 & Baik \\
7 & Teknis & 3,04 & Baik \\
8 & Keuangan & 2,78 & Kurang Baik \\
\hline
\end{tabular}

\section{Pengaruh kategori baik dan tidak baik}

Jumlah responden dengan kategorik baik ternyata tidak berbanding lurus dengan tingkat pengembalian modal usaha tepat waktu. Peubah nilai sosial dengan kategori tidak baik memiliki nilai paling nyata dan sangat berpengaruh terhadap pengembalian modal usaha tidak tepat waktu. Untuk lebih jelasnya dapat dilihat pada Tabel 3 (crosstab atau tabulasi silang).

Tabel 3. Tabulasi silang (crosstab)

\begin{tabular}{|c|c|c|c|c|c|c|}
\hline \multirow{2}{*}{$\begin{array}{l}\text { Peubah Bebas } \\
\qquad(X)\end{array}$} & \multirow{2}{*}{ Kategori } & \multicolumn{3}{|c|}{$\begin{array}{c}\text { Pelunasan pengembalian modal } \\
\text { usaha }(\mathrm{Y})\end{array}$} & \multirow{2}{*}{$\begin{array}{c}\text { Nilai } \\
\text { Peluang } \\
(p-\text {-Value })\end{array}$} & \multirow{2}{*}{ Keterangan } \\
\hline & & $\begin{array}{c}\text { Tidak tepat } \\
\text { waktu }\end{array}$ & $\begin{array}{l}\text { Tepat } \\
\text { waktu }\end{array}$ & Total & & \\
\hline \multirow[t]{3}{*}{ Nilai sosial } & Tidak Baik & 6 & 7 & 13 & \multirow{3}{*}{0,002} & \multirow{3}{*}{$\begin{array}{l}\text { Ada Hubungan } \\
\quad \text { (nyata) }\end{array}$} \\
\hline & Baik & 2 & 35 & 37 & & \\
\hline & Total & 8 & 42 & 50 & & \\
\hline \multirow[t]{3}{*}{ Nilai Teori } & Tidak Baik & 8 & 20 & 28 & \multirow{3}{*}{0,006} & \multirow{3}{*}{ Ada Hubungan } \\
\hline & Baik & 0 & 22 & 22 & & \\
\hline & Total & 8 & 42 & 50 & & \\
\hline \multirow[t]{3}{*}{ Nilai Ekonomi } & Tidak Baik & 8 & 23 & 31 & \multirow{3}{*}{0,015} & \multirow{3}{*}{$\begin{array}{l}\text { Ada Hubungan } \\
\text { (nyata) }\end{array}$} \\
\hline & Baik & 0 & 19 & 19 & & \\
\hline & Total & 8 & 42 & 50 & & \\
\hline \multirow{3}{*}{$\begin{array}{c}\text { Nilai } \\
\text { Keagamaan }\end{array}$} & Tidak Baik & 6 & 21 & 27 & \multirow{3}{*}{0,182} & \multirow{3}{*}{$\begin{array}{c}\text { Tidak Ada } \\
\text { Hubungan (Tidak } \\
\text { nyata) }\end{array}$} \\
\hline & Baik & 2 & 21 & 23 & & \\
\hline & Total & 8 & 42 & 50 & & \\
\hline \multirow{3}{*}{$\begin{array}{l}\text { Kemampuan } \\
\text { Usaha }\end{array}$} & Tidak Baik & 8 & 17 & 25 & \multirow{3}{*}{0,002} & \multirow{3}{*}{$\begin{array}{l}\text { Ada Hubungan } \\
\text { (nyata) }\end{array}$} \\
\hline & Baik & 0 & 25 & 25 & & \\
\hline & Total & 8 & 42 & 50 & & \\
\hline \multirow[t]{3}{*}{ Keuangan } & Tidak Baik & 8 & 15 & 23 & \multirow{3}{*}{0,001} & \multirow{3}{*}{$\begin{array}{l}\text { Ada Hubungan } \\
\text { (nyata) }\end{array}$} \\
\hline & Baik & 0 & 27 & 27 & & \\
\hline & Total & 8 & 42 & 50 & & \\
\hline \multirow[t]{3}{*}{ Manajerial } & Tidak Baik & 8 & 22 & 30 & \multirow{3}{*}{0,110} & \multirow{3}{*}{$\begin{array}{l}\text { Ada Hubungan } \\
\text { (nyata) }\end{array}$} \\
\hline & Baik & 0 & 20 & 20 & & \\
\hline & Total & 8 & 42 & 50 & & \\
\hline \multirow[t]{3}{*}{ Teknis } & Tidak Baik & 8 & 18 & 26 & \multirow{3}{*}{0,003} & \multirow{3}{*}{$\begin{array}{l}\text { Ada Hubungan } \\
\text { (nyata) }\end{array}$} \\
\hline & Baik & 0 & 24 & 24 & & \\
\hline & Total & 8 & 42 & 50 & & \\
\hline
\end{tabular}




\section{Analisis Logistic Regression}

Peubah bebas $(X)$ yang digunakan dalam analisis regresi logistik dapat berupa peubah kategorik ataupun peubah numerik. Fungsinya untuk menduga besarnya peluang kejadian dari peubah terikat $(\mathrm{Y})$, sedangkan peubah terikat sendiri haruslah peubah kategorik. Dengan kata lain, analisis regresi logistik merupakan suatu teknik untuk menerangkan peluang kejadian tertentu dari kategori peubah terikat. Pada penelitian ini, digunakan analisis regresi logistik biner.

Di dalam analisis regresi logistik biner, pemodelan peluang kejadian dari kategori peubah respon dilakukan melalui transformasi logit. Formula dari transformasi logit tersebut adalah:

$$
\operatorname{Logit}(\mathrm{pi})=\log _{\mathrm{e}}\left(\frac{\mathrm{pi}}{1-\mathrm{pi}}\right)
$$

Dengan pi adalah peluang munculnya kejadian kategori sukses dari peubah terikat untuk orang ke-i dan $\log _{\text {e }}$ adalah logaritma dengan basis bilangan e.. Kategori sukses secara umum merupakan kategori yang menjadi perhatian dalam penelitian. Dalam penelitian ini yang dimaksud dengan kategori sukses adalah tepat waktu dalam pengembalian modal usaha pada program KUM3 Kota Bogor.

Untuk mendapatkan informasi akurat terkait peluang dari setiap peubah penjelas $(X)$ yang dapat menyebabkan terjadinya pengembalian modal tidak tepat waktu, maka digunakan analisis regresi logistik berganda dengan delapan peubah bebas $(X)$ meliputi Sosial UKM $\left(X_{1}\right)$, Pengetahuan UKM $\left(X_{2}\right)$, Ekonomi UKM $\left(X_{3}\right)$, Agama UKM $\left(X_{4}\right)$, Pemasaran UKM $\left(X_{5}\right)$, Keuangan UKM $\left(X_{6}\right)$, Manajerial UKM $\left(X_{7}\right)$, Teknis UKM $\left(X_{8}\right)$ dan satu peubah terikat, yaitu pengembalian modal usaha pada program KUM3 Kota Bogor (Y).

Analisis model logistik dihasilkan dengan menggunakan software Statistical Package for Social Science (SPSS) 20 untuk menganalisa data responden sebanyak 50 orang. Data yang dianalisis menggunakan pengkodean peubah respon, yakni $1=$ tepat waktu dalam pengembalian modal usaha dan $0=$ tidak tepat waktu. Regresi logistik tidak linear, maka interpretasi parameter modelnya tidak bisa menggunakan koefisien beta, akan tetapi nilai OR $(\exp (B))$. Penjelasannya sebagai berikut:

a. Nilai slope peubah nilai sosial 1,866. Nilai positif menunjukkan bahwa peserta KUM3 dengan nilai sosial baik mempunyai kecenderungan mengalami pengembalian modal usaha tepat waktu lebih tinggi bila dibandingkan dengan nilai sosial yang kurang baik. Nilai Exp (B) 6,46 dapat diartikan peserta KUM3 dengan nilai sosial baik mempunyai kecenderungan mengalami pengembalian modal usaha tepat waktu lebih cepat 6,46 kali dibandingkan nilai sosial kurang baik.

b. Untuk peubah nilai teori slope sebesar 19,392. Nilai slope positif menunjukkan bahwa peserta KUM3 dengan nilai teori yang baik mempunyai kecenderungan mengalami pengembalian modal usaha tepat waktu lebih tinggi dibandingkan dengan nilai teori yang kurang baik. Dengan nilai $\operatorname{Exp(B)}$ sebesar 2,6E+08 dapat diartikan bahwa peserta KUM3 dengan nilai teori yang baik mempunyai kecenderungan mengalami pengembalian modal usaha tepat waktu 2,6E+08 kali dibandingkan nilai teori yang kurang baik.

c. Peubah nilai ekonomi memiliki nilai slope $-33,45$. Nilai negatif menunjukkan peserta KUM3 dengan nlai ekonomi baik mempunyai kecenderungan mengalami pengembalian modal usaha tepat waktu lebih rendah dibandingkan dengan nilai ekonomi kurang. Nilai $\operatorname{Exp}(B)$ 3E-15 dapat diartikan bahwa peserta KUM3 dengan nilai ekonomi baik mempunyai kecenderungan mengalami pengembalian modal usaha tepat waktu 3E-15 kali dibandingkan dengan nilai teori kurang baik.

d. Peubah nilai agama slope 1,242 . Nilai positif menunjukkan peserta KUM3 dengan nilai agama baik mempunyai kecenderungan mengalami pengembalian modal usaha tepat waktu lebih tinggi dibandingkan dengan nilai agama kurang baik. Nilai Exp (B) 3,46 dapat diartikan bahwa peserta KUM3 dengan nilai agama baik mempunyai kecenderungan mengalami pengembalian modal usaha tepat waktu 3,46 kali dibandingkan nilai agama kurang baik.

e. Peubah pemasaran dengan slope 18,842 . Nilai positif menunjukkan bahwa peserta KUM3 dengan pemasaran baik mempunyai kecenderungan mengalami pengembalian modal usaha tepat waktu lebih tinggi dibandingkan dengan pemasaran kurang baik. Nilai Exp (B) 1,5E+08 dapat diartikan bahwa peserta KUM3 dengan pemasaran yang baik mempunyai kecenderungan mengalami pengembalian 
modal usaha tepat waktu 1,5E+08 kali dibandingkan pemasaran kurang baik.

f. Peubah keuangan memiliki slope 32,343. Nilai positif menunjukkan bahwa peserta KUM3 dengan keuangan baik mempunyai kecenderungan mengalami pengembalian modal usaha tepat waktu lebih tinggi dibandingkan dengan keuangan yang kurang baik. Nilai Exp (B) 1,1E+14 dapat diartikan bahwa peserta KUM3 dengan keuangan baik mempunyai kecenderungan mengalami pengembalian modal usaha tepat waktu 1,1E+14 kali dibandingkan dengan keuangan kurang baik.

g. Peubah manajemen memiliki slope $-34,111$. Nilai negatif menunjukkan peserta KUM3 dengan manajemen kurang baik mempunyai kecenderungan mengalami pengembalian modal usaha tidak tepat waktu lebih tinggi dibandingkan dengan manajemen baik, meskipun rasio keduanya tidak nyata secara statistik. Nilai Exp (B) 1,5E-15 dapat diartikan bahwa peserta KUM3 dengan manajemen baik mempunyai kecenderungan mengalami pengembalian modal usaha tepat waktu 1,5E15 kali dibandingkan dengan manajemen kurang baik.

h. Peubah teknis memiliki slope 17,12. Nilai negatif menunjukkan peserta KUM3 dengan teknis baik mempunyai kecenderungan mengalami pengembalian modal usaha tepat waktu lebih rendah dibandingkan dengan teknis kurang baik. Nilai $\operatorname{Exp}$ (B) 2,7E+07 dapat diartikan bahwa peserta KUM3 dengan teknis baik mempunyai kecenderungan mengalami pengembalian modal usaha tepat waktu 2,7E+07 kali dibandingkan dengan teknis kurang baik.

Dari hasil perhitungan yang telah dijabarkan, maka faktor yang berpeluang menyebabkan pengembalian modal usaha tepat waktu adalah hanya nilai sosial yang nyata secara statistika pada $\alpha=10 \%$. Akan tetapi untuk analisa statistika yang lebih akurat, dapat dilanjutkan dengan metode stepwise (backward likelihood ratio).

\section{Multiple Logistic Regression (Backward Likeli- hood Ratio Method)}

Setelah menggunakan metode Backward Likelihood Ratio, proses analisa melewati tujuh langkah dan langkah terakhir adalah metode terbaik yang digunakan mengambil keputusan atau yang disajikan dalam pembahasan berikut merupakan model akhirnya. Dalam hal ini, peubah yang tersisa meliputi nilai sosial dan teknis.

Tabel 4. Correct classification table

\begin{tabular}{llllr}
\hline Observed & \multicolumn{4}{c}{ Predicted } \\
\hline \multirow{3}{*}{ Step 1 } & \multicolumn{4}{c}{ Pengembalian modal usaha } \\
\cline { 2 - 5 } & Tidak B & 0 & 8 &, 0 \\
& Baik & 0 & 42 & 100,0 \\
Over all \% & & & & 84,0 \\
\hline
\end{tabular}

a. The cut value is, 500

Output di atas adalah tabel kesesuaian klasifikasi (correct classification table). Tabel ini digunakan untuk mengetahui ketepatan prediksi dari model. Pada Tabel 4 diperoleh nilai asal peubah terikat dengan nilai prediksinya berdasarkan analisis regresi logistik biner. Dari tabel tersebut diperoleh hasil prediksi dengan rataan prediksi yang benar $84.0 \%$. Hal ini menunjukkan bahwa model yang digunakan adalah baik.

\section{Analisis Kelayakan Model Regresi Logistik}

Dasar pengambilan keputusan untuk menilai kelayakan analisis regresi logistik dengan melihat nilai goodness of fit test yang diukur dengan nilai khi kuadrat (chi square). Jika probabilitas >0,05 maka $\mathrm{H}_{0}$ diterima, artinya tidak ada perbedaan antara klasifikasi yang diprediksi dengan klasifikasi yang diamati, sebaliknya jika peluang <0,05 maka $\mathrm{H}_{0}$ ditolak, artinya ada perbedaan antara klasifikasi yang diprediksi dengan klasifikasi yang diamati. Angka peluang 0,819>0,05, maka $\mathrm{H}_{0}$ diterima (Tabel 5). Hal ini berarti model regresi logistik layak dipakai untuk analisis selanjutnya, karena tidak ada perbedaan nyata antara klasifikasi yang diprediksi dengan klasifikasi yang diamati.

Tabel 5. Hosmer and Lemeshow Test

\begin{tabular}{cccc}
\hline Step & Chi-square & $d f$ & sig \\
\hline 1 & 0,400 & 2 & 0,819 \\
\hline
\end{tabular}

\section{Analisis Keseluruhan Model/Overall Model Fit (Uji G)}

Untuk menilai keseluruhan model dilakukan dengan membandingkan nilai $-2 \quad$ Log Likelihood (-2LL) pada awal (Block number $=0$ ) dimana model hanya memasukkan konstanta dengan nilai -2 Log Likelihood (-2LL) pada akhir 
(Block number=1), dimana model memasukkan konstanta dan peubah bebas. Nilai -2LL awal 33,483 dan setelah dimasukkan tujuh peubah bebas maka nilai -2LL mengalami penurunan menjadi 25,920. Penurunan nilai -2LL ini menunjukkan model regresi yang baik atau dengan kata lain model yang dihipotesiskan fit dengan data (Tabel 6).

Output pada nilai -2(L( )-L1) adalah 33.483 merupakan nilai sosial koefisien 1.289 dan 0.872 untuk teknis. Artinya untuk nilai sosial dan teknis mempunyai pengaruh terhadap pengembalian modal usaha tidak tepat waktu.

Tabel 6. Iteration History

Iteration History ${ }^{a, b, c}$

\begin{tabular}{lccr}
\hline \multirow{2}{*}{ Iteration } & $\begin{array}{c}-2 \text { Log } \\
\text { likelihood }\end{array}$ & \multicolumn{2}{c}{ Coefficients } \\
\cline { 3 - 4 } & & Sosial & Teknis \\
\hline $\begin{array}{l}\text { Step 1 } \\
\text { (awal) }\end{array}$ & 33,483 & 1,289 & 0,872 \\
$\begin{array}{l}\text { Step 20 } \\
\text { (akhir) }\end{array}$ & 25,92 & 1,946 & 19,744 \\
\hline
\end{tabular}

\section{Pengujian Model Logistik secara Parsial (Uji Wald)}

Uji Wald digunakan untuk menguji model secara parsial atau menguji keberartian perbedaan peubah independen terhadap peubah dependen setelah semua uji dilakukan maka persamaan logit diperlukan tabel Variables in the Equation (Tabel 7).

Tabel 7. Variables in the Equation

\begin{tabular}{lllll}
\hline & B & S.E & Wald & Sig \\
\hline Sosial & 1,946 & 0,756 & 6,626 & 0,01 \\
Teknis & 19,744 & 7910,269 & 0 & 0,998 \\
Keluarga & 1,992 & 1,084 & 3,381 & 0,066 \\
Masyarakat & 2,068 & 1,208 & 2,932 & 0,087 \\
\hline Df=1 & & & &
\end{tabular}

Berdasarkan uji individu dengan uji Wald, didapatkan koefisien nilai sosial dan teknis nyata secara statistik pada $\alpha=5 \%$, sedangkan koefisien lainnya tidak nyata. Untuk peubah yang tidak nyata tidak akan dikeluarkan dari model, dengan mempertimbangkan model logistik dalam membandingkan proporsi suatu kelompok dengan kelompok lain dan mempertimbangkan satu atau beberapa faktor lain. Oleh karena itu bila terdapat koefisien yang tidak nyata maka akan dikatakan bahwa rasio keduanya tidak nyata (Usman, 2008).

\section{Interpretasi peubah}

Pengaruh nilai sosial terhadap pengembalian modal usaha (Y). Dari output pengolahan data statistik, diperoleh nilai koefisien regresi 1,946 dan nilai-p 0,010 $(<0,05)$. Hal tersebut berarti bahwa bahwa sosial value berpengaruh nyata terhadap pengembalian modal usaha tepat waktu pada taraf nyata $5 \%$.

Pengaruh teknis dan nilai sosial terhadap pengembalian modal usaha (Y). Dari output diperoleh nilai koefisien regresi 19,744 dan nilai-p $0,998(>0,05)$. Hal tersebut berarti bahwa teknis tidak berpengaruh nyata terhadap kelancaran dalam pengembalian modal usaha pada taraf nyata $5 \%$.

Nilai sosial yang paling berpengaruh terhadap pengembalian modal usaha antara peubah keluarga dan masyarakat dapat dilihat lebih jauh. Dari output diperoleh nilai keluarga dengan koefisien regresi 1,992 dan nilai -p 0,066 $(<0,10)$. Berdasarkan hal tersebut dapat disimpulkan bahwa keluarga berpengaruh nyata terhadap kelancaran dalam pengembalian modal usaha pada taraf nyata $10 \%$ koefisien regresi 2,068 dan nilai -p 0,087 $(<0,10)$.

Masyarakat berpengaruh nyata terhadap kelancaran dalam Pengembalian modal usaha pada taraf nyata $10 \%$. Berdasarkan perbandingan faktor keluarga dan masyarakat dalam nilai sosial, maka keduanya berpengaruh terhadap pengembalian modal. Akan tetapi berdasarkan nilai peluangnya dapat dilihat bahwa keluarga $(0,066)$ memiliki nilai peluang lebih baik dari masyarakat $(0,087)$.

Dari interpretasi peubah nilai sosial cukup baik, akan tetapi paling berpengaruh dalam pengembalian modal usaha. Jika peserta dalam program KUM3 ini memiliki nilai sosial kurang baik, maka peluang peserta dalam pengembalian modal usaha tidak tepat waktu lebih tinggi. Berbeda hasilnya jika seorang peserta dapat mengatur waktunya dengan baik, meskipun nilai sosial baik, tidak akan berpeluang menyebabkan pengembalian modal usaha tidak tepat waktu.

Berdasarkan perbandingan faktor keluarga dan masyarakat dalam nilai sosial, keduanya berpengaruh terhadap pengembalian modal usaha tidak tepat waktu. Berdasarkan nilai peluangnya, dapat dilihat bahwa keluarga memiliki nilai peluang lebih baik dari masyarakat.

Peubah yang mempunyai hubungan positif dan tidak nyata terhadap pengembalian modal usaha tidak tepat waktu, yaitu peubah nilai 
agama, pemasaran, keuangan dan manajemen. Semua peubah tersebut mempunyai peluang untuk memengaruhi pengembalian modal usaha tidak tepat waktu, hanya saja perubahan yang terjadi dalam peubah tersebut kurang nyata atau kurang berpengaruh terhadap pengembalian modal usaha. Hal ini dikarenakan:

a. Meskipun hampir seluruh nilai agama peserta KUM3 kurang baik, tetapi para peserta tetap membayar angsuran kepada BMM, sehingga perubahan yang terjadi pada nilai agama peserta tidak nyata terhadap pembayaran hutangnya kepada BMM. Hal ini berarti bahwa para peserta lebih mengedepankan kearifan lokal dalam masalah utang piutang dan masih mempunyai norma kesusilaan atau moral yang baik.

b. Pemasaran produk yang dijual oleh hampir seluruh peserta adalah baik, sehingga peserta KUM3 tidak melihat faktor pemasaran sebagai kendala dalam pengembalian modal usaha kepada BMM maka faktor pemasaran bagi peserta KUM3 menjadi tidak nyata terhadap pembayaran angsuran. Hal ini berarti peserta telah melakukan analisis pasar cukup baik, sehingga diambil kesimpulan hampir seluruh peserta KUM3 mempunyai nilai ekonomi dan pemasaran baik akan mempunyai peluang tinggi untuk mengembalikan modal usaha kepada BMM.

c. Pengelolaan keuangan yang dilakukan oleh sebagian besar peserta KUM3 adalah baik, sehingga peserta KUM3 tidak melihat faktor keuangan ini sebagai kendala dalam pengembalian modal usaha kepada BMM, yang menyebabkan faktor keuangan bagi peserta KUM3 menjadi tidak nyata terhadap pembayaran hutangnya kepada BMM. Hal ini tentunya merupakan keberhasilan pendamping peserta dalam membina peserta KUM3.

d. Meskipun sebagian besar manajemen peserta KUM3 kurang baik, tetapi para peserta tetap membayar angsuran kepada BMM, sehingga perubahan yang terjadi pada manajemen peserta KUM3 tidak nyata terhadap pembayaran hutangnya kepada BMM.

Peubah lainnya yang tidak ada hubungan dan tidak nyata terhadap pengembalian modal usaha tidak tepat waktu, yaitu teknis. Teknis mempunyai peluang memengaruhi pengembalian modal usaha tidak tepat waktu, hanya saja perubahan yang terjadi dalam peubah tersebut tidak nyata atau tidak berpengaruh terhadap pengembalian modal usaha, maka dapat dipahami bahwa meskipun pemahaman peserta terhadap perjanjian, hutang piutang, masih kurang baik, namun tetap mengembalikan modal usaha kepada BMM. Hal ini berarti para peserta masih memprioritaskan pembayaran hutang kepada pihak BMM akibat pemahaman tentang hutang dalam Islam.

\section{KESIMPULAN}

1. Faktor-faktor yang memengaruhi pengembalian modal usaha adalah faktor karakter yang terdiri dari nilai sosial, nilai teori, nilai ekonomi, nilai agama dan faktor kemampuan yang terdiri dari pemasaran, keuangan, manajerial dan tekni. Faktor-faktor tersebut berpengaruh terhadap pengembalian modal usaha pada program KUM3 Kota Bogor. Faktor nilai sosial berpengaruh dalam pengembalian modal usaha paling nyata dan berbanding terbalik dengan nilai agama yang tidak berpengaruh dalam pengembalian modal usaha.

2. Responden melakukan pembayaran tepat waktu dengan kategori nilai sosial baik, 7.000 kali dibandingkan dengan responden dengan nilai sosial tidak baik, dimana pengaruh keluarga berperan terhadap kelancaran dalam pembayaran angsuran pada tarap nyata $10 \%$

3. Strategi pendamping diperlukan dalam mengelola dana dan meminimalisir pengembalian modal usaha tidak tepat waktu. Dalam hal ini pendamping program KUM3 Kota Bogor mencontoh Rasulullah dalam melakukan pembinaan pesertanya dengan memakmurkan masjid. Secara keseluruhan peserta KUM3 dapat mengembalikan modal usaha tepat waktu.

\section{DAFTAR PUSTAKA}

Ahmad, J. 2008. Fikih Ekonomi Umar bin Al-Khatab. Jakarta: Khalifa.

Antonio, M. S. 2001. Bank Syariah Dari Teori Ke Praktik.Jakarta: Gema Insani Press.

Arikunto, S. 1998. Prosedur Penelitian Suatu Pendekatan Praktek. Jakarta: PT Rineka Cipta.

Herimanto. 2010. Ilmu Sosial \& Budaya Dasar. Jakarta: PT. Bumi Aksara

Ismail. 2010. Akutansi Bank: Teori dan Aplikasi Dalam Rupiah. Jakarta: Kencana Prenada Media Group. 
Mangkunegara, A.A.P. 2005. Manajemen Sumber Daya Manusia Perusahaan. Bandung: PT Remaja Rosdakarya.

Natzir, M. 2005. Design Penelitian. Jakarta: Gramedia Pustaka Utama.

Mufraini, M.A. 2006. Akutansi dan Manajemen Zakat Mengomunikasikan Kesadaran dan Membangun Jaringan. Jakarta: Kencana Prenada Media Group.

Rasyid, A.H. 1994. Dasar-Dasar Statistika Terapan, Bandung: Program Pascasarjana Unpad.
Rivai, V., Andria P.V. 2008. Islamic Financial Management. Jakarta: Raja Grafindo Persada

Rodoni, A. 2008. Lembaga Keuangan Syariah. Jakarta: PT. Bestari Buana Murni.

Simamora, H. 2004. Manajemen Sumber Daya Manusia. Edisi III, Yogyakarta: STIE YPKN.

Sugiyono. 2009. Metode Penelitian Administrasi. Bandung: CV. ALFABETA

Baitul Maal Muamalat. 2013. Annual report 21 Februari 2013. Jakarta: Baitul Maal Muamalat. 